\title{
Relevansi Bahan Ajar dengan Standar Isi Kurikulum MI/SD Kelas V Tema I (Organ Gerak Hewan dan Manusia) Terbitan Citra Pustaka
}

\author{
${ }^{1}$ Siti Nurul Fitriani, ${ }^{2}$ Baiq Zunnur'aeni Yusmayani \\ ${ }^{1,2}$ Prodi PGMI IAI Hamzanwadi NW Pancor \\ Email: ${ }^{1}$ sitinurulfitriani91@gmail.com
}

\begin{abstract}
Abstrak
Tujuan dari penelitian ini adalah untuk mengetahui relevansi bahan ajar dengan standar isi kurikulum MI/SD Kelas V pada tema organ gerak hewan dan manusia terbitan citra pustaka. Agar tidak terjadi permasalahan di masa mendatang, buku ajar harus sesuai dengan kurikulum yang berlaku saat ini yaitu sesuai dengan Stadar Isi Kurikulum MI/SD yang disebutkan dalam Standar Nasional Pendidikan (SNP). Adapun jenis penelitian yang digunakan yaitu Library Research (Penelitian Kepustakaan) dengan 2 sumber data, data primer dan sekunder.

Data primer, yang merupakan sumber utama penelitian ini yaitu buku ajar kelas V MI/D Semester 1 terbitan Citra Pustaka, sedangkan data sekunder yang berasal dari berbagai sumber bacaan seperti jurnal-jurnal, buku, artikel, dan blog di internet yang berkaitan dengan kajian peneliti. Analisis data dilakukan dengan model Miles dan Huberman, dengan cara menganalisis data dengan mereduksi, display dan menggambarkan kesimpulan, Hasil dari penelitian ini menunjukkan bahwa isi dari buku ajar kelas V terbitan citra pustaka sudah sesuai dengan Standar isi Kurikulum MI/SD (Standar Kompetensi Lulusan (SKL) dari kompetensi inti dan kompetensi dasarnya) walaupun tidak bisa dipungkiri bahwa masih terdapat kekurangan-kekurangan namun buku ini sudah memenuhi unsure-unsur yang terdapat pada standar kurikulum 2013.
\end{abstract}

Kata kunci: Relevansi Bahan Ajar, Standar Isi Kurikulum MI/SD, Buku Ajar terbitan Citra Pustaka 


\section{PENDAHULUAN}

Pendidikan nasional adalah pendidikan yang berdasarkan Pancasila dan Undang-Undang Dasar Negara Republik Indonesia Tahum 1945 yang berakar pada nilai-nilai agama, kebudayaan nasional Indonesia dan tanggap terhadap tuntunan perubahan zaman ${ }^{1}$. Sistem pendidikan nasioanal adalah keseluruhan komponen pendidikan yang saling terkait secara terpadu untuk mencapi tujuan pendidikan nasional. Sedangkan di dalam Undang-Undang No 20 tahun 2003 bahwa pendidikan nasional yang berdasarkan Pancasila dan Undang-Undang Dasar Negara Republik Indonesia Tahun 1945 berfungsi mngembangkan kemampuan dan membentuk watak serta peradaban bangsa yang bermartabat dalam rangka mencerdaskan kehidupan bangsa, bertujuan untuk mengembangkan potensi peserta didik agara menjadi manusia yang beriman dan bertakwa kepada Tuhan Yang Maha Esa, berakhlak mulia, sehat, berilmu, cakap, kreatif, mandiri, dan menjadi warga negara yang demokratis serta bertanggung jawab. ${ }^{2}$

Pendidikan nasioanal harus mampu menjamin pemerataan kesempatan pendidikan, peningkatan mutu dan relevansi serta efisiensi manajemen pendidikan. Pemerataan kesempatan pendidikan diwujudkan dalam program wajid belajar 9 tahun. Untuk mencapai tujuan proses pembelajaran harus didukung oleh faisilitas yang mendukung pembelajaran, sampai saat ini buku pelajaran memengang penting sebagai pendukung proses pembelajaran baik di sekolah maupun dirumah.

Dalam proses pendidikan, buku pelajaran merupakan salah satu bahan ajar yang wajib ada dilembaga pendidikan baik lembaga pendidikan formal maupun nonformal. Karena didalamnya terdapat ilmu pengetahuan, informasi, dan bisa juga hiburan, yang peserta didik bisa dapatkan. Sedangkan kurikulum merupakan alat untuk mencapai tujuan pendidikan. Tanpa kurikulum yang sesuai dan tepat akan sulit untuk mencapai tujuan dan sasaran pendidikan yang diinginkan. Untuk

\footnotetext{
${ }^{1}$ Ali Imron, Kebijakan Pendiidkan di Indonesia, Proses, Produk Masa Depannya, (Jakarta: Bumi Aksara, 2002) h. 3

${ }^{2}$ UU No. 20 Tahun 2003, tentang Sistem Pendidikan Nasional, Pasal 3.
}

Vol. 2, No. 2, Desember 2020 
itu buku ajar yang baik memiliki kriteria tertentu atau standar tertentu seperti tentang relevansinya dengan kurikulum yang sedang berlaku saat ini. ${ }^{3}$

Sebagai alat yang penting untuk mencapai tujuan, kurikulum hendaknya bisa menyesuaikan dengan perubahan zaman dan kemajuan ilmu pengetahuan dan canggihnya teknologi, selain itu kurikulum berkembang sejalan dengan perkembangan teori dan praktik pendidikan. Selain itu kurikulum juga harus bisa memberikan arahan dan patokan keahlian kepada peserta didik setelah menyelesaikan suatau program pengajaran pada suatu lembaga. Dalam realitas sejarah pendidikan, Indonesia telah berulang kali melakukan perubahan kurikulum mulai dari Rentjana Pembelajaran 1947, Rentjana Pelajaran Terurai 1952, Kurkulum 1964, Kurikulum 1968, Kurikulum 1975, Kurikulum 1984, Kurikulum 1994, Kurikulum 2004 atau KBK (Kurikuum Berbasis Komputer), Kurikulum 2006 atau KTSP (Kurikulum Tingkat Satuan Pendidikan), ${ }^{4}$ hingga Kurikulum yang baru saja ditetapkan di tahun 2013 yaitu Kurikulum 2013.

Sebagai konsekuensi dari diberlakukannya kurikulum 2013, dimana Kompetensi Inti menjadi acuan utama yang merupakan pengikat kompetensikompetensi yang harus dihasilkan melalui proses pembelajaran dalam setiap mata pelajaran, maka dalam penyusunan buku teks pelajaran harus dapat mengantarkan pesrta didik pada Kompetensi Inti yang diinginkan, tidak terkecuali pada bahan ajar tematik. Untuk itu perlunya ditelaah lebih lanjut apakah terdapat hal-hal yang perlu dibenahi dan disempurnakan agar mengetahui buku yang digunakan sesuai dengan kurikulum yang ada dari segi isi, strategi dan bahkan media pembelajaran yang digunakan.

Dari penjelasan di atas maka isi dari suatu buku ajar harus relevan dengan kurikulum yang berlaku sehingga tidak terjadi permasalahan. Pelajaran di MI/SD sekarang ini yang tidak dapat dipisahkan dari bahan ajar tematuk yang harus sesuai dengan kurikulum yang telah berlaku saat ini yakni sesuai dengan Standar

\footnotetext{
${ }^{3}$ Moh. Yamin, Manajemen Mutu Kurikulum Pendidikan, (Yogyakarta: Dive Press, Cet-2 Februari 2010), h. 36.

${ }^{4}$ Nur Sholeh, Sejarah Perkembangan Kurikulum Bahasa Arab Madrasah Aliyah 1984-2006, Tesis, (Yogyakarta: UIN Sunan Kalijaga, 2012) h. 3
}

Vol. 2, No. 2, Desember 2020 
Isi Kurikulum MI/SD, yang disebutkan dalam SNP (Standar Nasional Pendidikan), sehingga ada relevansi antar isi buku ajar dengan kurikulum.

\section{Relevansi}

Menurut kamus besar Bahasa Indonesia, Relevansi adalah hubungan, kaitan: setiap mata pelajaran harusnya mempunyai kaitan dengan keseluruhan tujuan pendidikan. ${ }^{5}$ Seperti bahan ajar tematik isinya harus sesuai dengan kurikulum yang berlaku sekarang ini agar tujuan pendidikan itu bisa terujut sesuai dengan keinginan.

Ada dua macam relevansi menurut Nana Syaodih Sukmadinanta yaitu relevansi internal dan relevansi ekstrnal. Relevansi eksternal maksutnya tujuan, isi, dan proses belajar yang tercakup dalam kurikulum hendaknya relevan dengan tuntutan, kebutuhan, dan perkembangan masyarakat. Relevansi internal yaitu kesesuaian atau konsistensi antara komponen-komponen kurikulum, yaitu, antara tujuan isi, proses penyampaian dan penelitian. Relevansi internal ini menunjukkan suatu keterpaduan. ${ }^{6}$

\section{Standar Isi}

Standar isi adalah kriteria mengenai ruang lingkup materi dan tingkat kompetensi untuk mencapai kompetensi lulusan pada jenjang dan jenis pendidikan tertentu. Ruang lingkup materi dirumuskan berdasarkan kriteria muatan wajib. Sedangkan tingkat kompetensi dirumuskan berdasarkan kriteria tingkat perkembangan peserta didik, kualifikasi kompetensi Indonesia, dan penguasaan kompetensi yang berjenjang.

\section{Kurikulum K-13}

Kurikulum menurut UU No.20 Tahun 2003 pasal 1 ayat (19) adalah seperangkat rencana dan pengaturan mengenai tujuan, isi, dan bahan pelajaran serta cara yang digunakan sebagai penyelenggaraan kegiatan pembelajaran untuk mencapai tujuan pendidikan tertentu. Pengembangan kurikulum 2013 merupakan langkah lanjutan pengembangan Kurikulum Berbasis Komputer yang dirintis pada

\footnotetext{
${ }^{5}$ KBBI Offline 1.5.1

${ }^{6}$ Nana Syaodih Sukmadinanta, Pengembangan Kurikulum, Teori dan Praktek, (Bandung: Remaja Rosdakarya: 1997) h. 150
}

Vol. 2, No. 2, Desember 2020 
tahun 2004 dan KTSP 2006 yang mencangkup kompetensi sikap, pengetahuan, dan keterampilaan secara terpadu.

Secara eksplisit bahwa tujuan pendidikan nasional sebagai mana telah dirumuskan dalam Undang-Undang Nomor 20 Tahun 2003 adalah untuk berkembangnya potensi peserta didik agar menjadi manusia yang beriman dan bertakwa kepada Tuhan Yang Maha Esa, berakhlak mulia, sehat, berilmu, calap, kreatif, mandiri, dan menjadi warga negara yang demokratis serta bertanggung jawab. Begitu pula telah ditetapkan visi pendidikan tahun 2025 yaitu menciptakan insan Indonesia yang cerdas dan kompetitif. Cerdas yang dimaksud disini adalah cerdas komprehensif, yaitu cerdas spiritual dan cerdas sosial/emosional daram ranah sikap, cerdas intelektual dalam ranah pengetahuan, serta cerdas kinestetis dalam ranah keterampilan.

Untuk itu Kurikulum 20013 dibentuk dengan tujuan mempersiapkan insan Idonesia supaya memiliki kemampuan hidup sebagai peribadi dan warga negra yang beriman, produktif, kreatif, inovatif, dan afektif serta mampu berkonteribusi pada kehidupan bermasyarakat, berbangsa, bernegara, dan peradaban dunia. Kurikulum merupakan instrumen pendidikan untuk dapat membawa insan Indonesia memiliki kompetensi sikap, pengetahuan, dan keterampilan sehingga dapat menjadi pribadi dan warga negara yang produktif, kreatif, inovatif, dan afektif.

\section{Struktur Kurikulum 2013}

Struktur kurikulum 2013 relatif lebih ramping tetapi meambahkan jam pelajaran. Semula di kelas I, II, III masing-masing 26, 27, dan 28 jam pembelajaran (JPL) dan di kelas IV-VI adalah 32 JPL. Pada kurikulum 2013 ditambah menjadi 30-36 JPL.

Pada jenjang SD/MI, terdapat dua kelompok mata pelajaran yaitu kelompok A dan kelompok B. dimana kelompok A adalah kelompok mata pelajaran yang kontenya dikembangkan oleh pusat, sedankan kelompok B kontennya dikembangkan oleh pusat dan dilengkapi oleh konten muatan lokal dari pemerintah daerah. Sepeti mata pelajaran Seni Budaya dan Prakarya dapat 
memasukkan materi Bahasa Daerah yang setiap daerah pasti berbeda-beda sesuai suku bangsa masing-masing.

Seluruh konten mata pelajaran dikemas secara tematik terpadu, kecuali pendidikan agama dan budi pekerti agar materi umum dengan materi kegamaan yang diajarkan relevan sehingga tidak menimbulkan salah tafsir terhadap keyakinan agama.

Berdasarkan Permendikbud Nomor 67 Tahun 2013 tentang Kerangka Dasar dan Struktur Kurikulum Sekolah Dasar/Madrasah Ibtidaiyah, beban belajar di kelas I adalah 30 PJL per minggu; Kelas II adalah 32 JPL per minggu; Kelas III adalah 34 JPL per minggu; Kelas IV, V, dan VI adalah 36 JPL per minggu. Satu jam pelajaran memiliki durasi 35 menit. Pelaksanaan pembelajaran di kelas I, II, III, IV, dan V dalam satu semester paling sedikit 18 minggu dan paling banyak 20 minggu. Khusus untuk kelas VI, beban belajar pada semester genap paling sedikit 14 minggu dan paling banyak 16 minggu. Penambahan jumlah alokasi waktu per minggu di maksudkan untuk memberi kesempatan kepada guru dan peserta didik melaksanakan pembelajaran dengan pendekatan tematik.

\section{Pembelajaran Tematik}

Secara sederhana, istilah pembelajaran (instruction) bermakna sebagai upaya untuk mempelajarkan seseorang atau kelompok orang melalui bergai upaya (effort) dan menggunakan berbagai strategi, metode, dan pendekatan ke arah pencapaian tujuan yang telah direncanakan. ${ }^{7}$

Pembelajaran tematik merupakan suatu pendekatan dalam pembelajaran yang secara sengaja mengaitkan atau memadukan beberapa Kompetensi Dasar (KD) dan Indikator dari Kurikulum/Standar Isi (SI) dari beberapa mapel menjadi satu kesatuan untuk dikemas dalam satu tema. Dengan adanya kaitan tersebut maka peserta didik akan memproleh pengetahuan dan keterampilan secara utuh sehingga pembelajaran menjadi lebih bermakna bagai peserta didik. Dalam Peraturan Meneteri Pendidikan dan Kebudayaan (Permendikbud) No.57 tahun 2014 halaman 220 menyebutkan bahwa:

\footnotetext{
${ }^{7}$ Abdul Majid, Strategi Pembelajaran, (Bandung: PT. Remaja Rosdakarya: 2013) h. 4.
} 
"Pembelajaran tematik terpadu merupakan salah satu model pembelajaran terpadu yang menggunakan tema untuk mengaitkan beberapa mata pelajaran sehingga dapat memberikan pengalaman bermakna bagi peserta didik." 8

Pembelajaran tematik ini dikembangkan menurut paham konstruktivisme yang menyatakan bahwa pengetahuan dibentuk sendiri oleh individu dan pengalaman merupakan kunci utama dari belajar bermakna. Belajar bermakna tidak akan terwujud hanya dengan mendengarkan ceramah atau membaca buku tentang pengalaman orang lain. Pengalaman secara individual merupakan kunci kebermaknaan.

\section{METODE PENELITIAN}

Metode Penelitian adalah cara-cara berpikir dan berbuat yang dipersiapkan dengan baik untuk mengadakan penelitian dan mencaai suatu tujuan penelitian (Kartini Kartono: 1996, hal. 20). Metode yang digunakan dalam penelitian ini adalah sebagai berikut:

Jenis Penelitian, jenis penelitian yang digunakan adalah penelitian kepustakaan (Library Research), penelitian yang pengumpulan datanya dilakukan dengan menghimpun data dari berbagai literasi. Literatur yang diteliti tidak hanya terbatas pada buku-buku saja, tetapi dapat jaga berupa bahan-bahan dokumentasi, majalah-majalah, jurnal, dan surat kabar. Penelitian kepustakaan digunakan untuk memecahkan masalah penelitian yang bersifat konseptual-teoritis, baik tentang tokoh pendidikan atau konsep pendidikan tertentu seperti tujuan, metode, dan lingkungan pendidikan. ${ }^{9}$ Subjek penelitian ini adalah Bahan Ajar Tematik kelas V MI/SD Semester I terbitan Citra Pustaka.

Sumber data, sumber data yang digunakan ada dua macam yaitu data primer dan data sekunder. Data primer merupakan sumber utama yang digunakan dalam penelitian ini, yaitu buku ajar Tematik kelas V MI/SD terbitan Citra Pustaka. Sedangkan data sekunder bersumber dari berbagai macam literasi seperti

\footnotetext{
${ }^{8}$ Permendikbud No. 57 Tahun 2013 Lampiran 3 tentang Kurikulum 2013, h. 220.

9 Sarjono, dkk., Panduan Penulisan Pendidikan, (Yogyakarta: Jurusan Pendidikan Agama Islam Fakultas Tarbiyah Dan Keguruan UIN Sunan Kalijaga, 2008), h. 21
} 
jurnal-jurnal, majalah-majalah, website, atau blog-blog di internet yang mendukun dalam penyusunan skripsi ini.

Metode Pengumpulan Data, metode pengumpulan data yang digunakan adalah metode dokumentasi. Metode dokumentasi merupakan metode pengumpulan data dengan mencari data mengenai hal-hal atau variabel yang berupa catatan transkip, buku, surat kabar, notulen rapat,agenda, dan sebagainya. ${ }^{10}$ Dimana penelitian ini menyelidiki tentang kekurangan dan kelebihan bahan ajar tematik MI/SD kelas V terbitan Citra Pustaka, serta menelaah buku-buku tersebut mengenai relevansinya dengan standar isi kurikulum MI/SD kelas V.

Analisis Data yang digunakan dalam penelitian ini adalah analisis data model Miles and Huberman. Aktifitas analisis kualitatif dalam model ini dilakukan secara interaktif dan terus-menerus sampai dirasa cukup. Menurut Kaelan, ada dua tahap dalam teknik analisis data pada penelitian kepustakaan. Pertama, analisis saat, ini ditujukan untuk menangkap esesni atau inti dari focus penelitian yang akan dilakukan melalui sumber-sumber yang dikumpulkan.

Kedua, selanjutnya menganalisis kembali setelah data terkumpul yang berupa data mentah yang harus ditentukan hubungan satu sama lain. Data yang terkumpul tersebut belum tentu seluruhnya menjawab permasalahan yang dimunculkan dalam penelitian, untuk itu pelu dilakukan analisis data dengan cara meredukdi data, display data dan menggambarkan kesimpulan.

\section{HASIL PENELITIAN DAN PEMBAHASAN}

\section{A. Hasil Penelitian}

Sebagai perbandingan dalam penelitian ini, peneliti membandingkan buku terbitan Citra Pustaka dengan terbitan Permendikbud.

Pada suatu kegiatan pendidikan guru dan siswa menggunakan sumber belajar seperti buku ajar yang merupakan suatu kebutuhan yang tidak terelakkan lagi. Guru akan memilih buku ajar yang sesuai dengan materi pembelajaran. Karena buku ajar mempunyai peran penting dalam dunia pendidikan, sehingga

\footnotetext{
${ }^{10}$ Suharsimi Arikunto, Prosedur Penelitian Suatu Pendekatan Praktis, (Jakarta: Rieneka Cipta,
} 2006), h. 10

Vol. 2, No. 2, Desember 2020 
proses pembelajaran berjalan sesuai keinginan dan tujuan pembelajaran. Salah satunya di Madrasah Ibtidaiyah (MI)/Sekolah Dasar (SD) tidak bisa dipisahkan dari adanya media pembelajaran yang berbentuk buku ajar. Karena buku ajar mempunyai peran penting dalam kegiatan belajar mengajar dan banyak digunakan oleh sekolah-sekolah sekarang ini.

Untuk itu buku ajar yang digunakan dalam setiap jenjang pendidikan harus sesuai dengan standar kurikulum yang ada agar proses belajar mengajar yang dilakukan tidak sia-sia. Pemilihan buku ajar juga harus sesuai dengan apa yang dibutuhkan dalam proses pembelajaran. Seperti buku ajar terbitan Citra Pustaka yang digunakan dalam penelitian ini, isi atau materi yang disajikan sudah sesuai dengan standar kurikulum 2013.

Dalam buku terbitan Citra pustaka ini materi yang disajikan sudah sesuai dengan standar kurikulum lulusan dari KI dan KD-nya. Namun sebagian materi yang dijelaskan sangat singkat sehingga sebagian materi tidak sesuai dengan soal yang akan dikerjakan oleh siswa, sehingga siswa akan merasa kesulitan dalam mengerjakan soal tersebut.

Misalnya pada subtema 1 sampai subtema 3 pada mata pelajaran IPA materi yang disajikan sudah sesuai dengan standar kurikulum yang sudah ditetapkan. Namun, dalam beberapa bagian tentunya masih terdapat beberapa kekurangan diantaranya pada materi yang dijelaskan terutama keterkaitan materi dengan soal yang disajikan. Seperti pembelajaran 2 subtema 1 buku siswa terbitan Citra Pustaka ini menjelaskan sebagian materi yang harus dipelajari siswa dalam kurikulum yang sudah ada. Di mana dalam kurikulum materi yang dipelajari siswa adalah mengenai rangka organ gerak (kelinci, burung, ikan, katak, dan kadal). Namun dalam buku siswa terbitan Citra Pustaka ini hanya menjelaskan tentang rangka organ gerak ikan, burung, dan kelinci. Sedangkan soal yang harus dikerjakan siswa mengenai organ gerak katak. Contohnya adalah sebagai berikut:

\section{Avo Gart Tahn}

Carilah informasi mengenai sistem gerak pada katak! Apa șaja organ yang digunakan katak untuk bergerak? Jelaskan masing-masing dari organ gerak katak tersebut! Tulislah pada buku tugasmu dan gambarlah kerangka katak tersebut! 
Gambar 1 : Contoh Soal Subtema I

Hal tersebut tentunya tidak sesuai dengan kompetensi yang hendak dicapai. Memang dalam pembelajaran kurikulum 2013 ini bahan ajar yang digunakan tidak hanya menyajikan informasi langsung kepada siswa melainkan merangsang rasa ingin tahu siswa dengan menyajikan berbagai pertanyaanpertanyaan dalam setiap buku pelajaran, serta siswa dituntut untuk berpikir sendiri dan mengaitkannya dengan apa yang sudah dialami dalam kehidupan sehariharinya baik di sekolah, di rumah, maupun di lingkungan masyarakat.

Dalam buku terbitan Citra Pustaka ini juga tidak bisa dipungkiri masih terdapat kekurangan-kekurangan, baik dari sebagian penyajian materi yang sangat singkat dan sebagian soal yang disajikan bisa dikatakan membuat siswa berpikir keras untuk memecahkan soal tersebut agar jawabannya benar. Dimana dari segi penilaiannya juga masih kurang efektif untuk dijadikan pedoman oleh guru dalam memberikan nilai.

Sedangkan dalam buku siswa terbitan Permendikbud pada awal pembelajaran disajikan cerita untuk merangsang rasa ingin tahu siswa tentang isi buku tersebut. Contohnya dalam Tema 1 subtema 1 pemetaan KI dan KD tidak dipaparkan melainkan langsung ke pembelajaran 1. Dalam buku siswa terbitan permendikbud ini materi yang dijelaskan sudah sesuai dengan standar kurikulum 2013 yang ada. Namun materi yang dijelaskan sangat singkat tapi setelah penjelasan materi dalam buku ini terdapat sebuah contoh yang bisa dijadikan acuan oleh siswa agar benar-benar memahami materi yang dijelaskan. Contohnya sebagai berikut: 
Ide pokok adalah gagasan yang menjadi dasar sebuah paragraf. Ide pokok disajikan ke dalam bentuk kalimat dasar sebuah paragraf. Ide pokok ide pokok ini bisa berada kalimat utama. Kalimat utama yang memuat paragraf.

Contoh:

\section{PARAGRAF 1}

Ide Pokok

Salah satu ciri dari makhluk hidup adalah bergerak.

Kalimat Pengembang

Secara umum gerak dapat diartikan berpindah tempat atau perubahan posisi sebagian atau seluruh bagian dari tubuh makhluk hidup.

Gambar 2 : Contoh Ide Pokok Subtema 1 Permendikbud

Selain itu, meskipun semua materi yang disajikan sangat singkat, namun dalam setiap penjelasan materi dalam buku ini terdapat gambar-gambar yang sesuai dengan materi yang dijelaskan untuk dilihat oleh siswa agar mendapat gambaran dari penjelasan materi tersebut. Misalnya dalam pembelajaran 3 mata pelajaran PPKn materinya menjelaskan tentang nilai-nilai yang terkandung dalam sila-sila Pancasila, contohnya sebagai berikut:

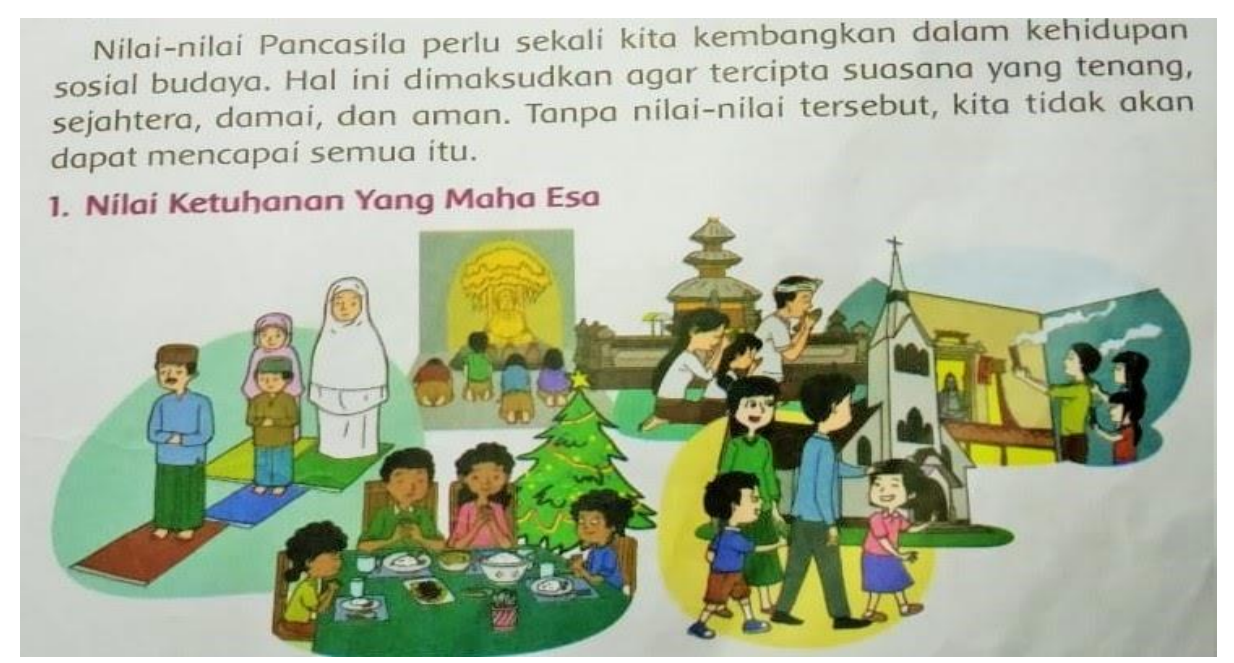

Gambar 3 : Materi PPKn Subtema I Permendikbud

Dari gambar yang disajikan siswa bisa menyimpulkan sendiri apa yang dimaksud dari penjelasan materi itu. Sehingga siswa lebih mudah memahami pelajaran dan tujuan dari pembelajaran itu sendiri bisa terwujud dengan baik.

Dari penjelasan di atas dapat disimpulkan bahwa buku terbitan Citra pustaka dengan buku terbitan Permendikbud terletak pada penjelasan materi dan soal yang harus dikerjakan siswa. Dimana pada buku terbitan Citra Pustaka materi 
yang dijelaskan sudah sesuai dengan standar Kurikulum 2013 hanya saja dalam setiap penjelasan tidak disajikan satupun contoh yang bisa dijadikan acuan oleh siswa agar lebih memahami materi tersebut. Dalam buku ini juga menyajikan soal yang himbauannya menyuruh siswa untuk belajar bersama orang tuanya dirumah untuk memecahkan suatu masalah, setelah semua pembahsan dipelajari dari subtema 1 sampe subtema 3 terdapat penilaian yang berbentuk soal pilihan dan uraian yang mencangkup semua mata pelajaran yang ada pada Teama 1 untuk dijawab oleh siswa. Soal yang dibuat untuk mengetahui apakah siswa sudah menguasai kompetensi dasar yang sudah dipelajari. Contohnya sebagai berikut:

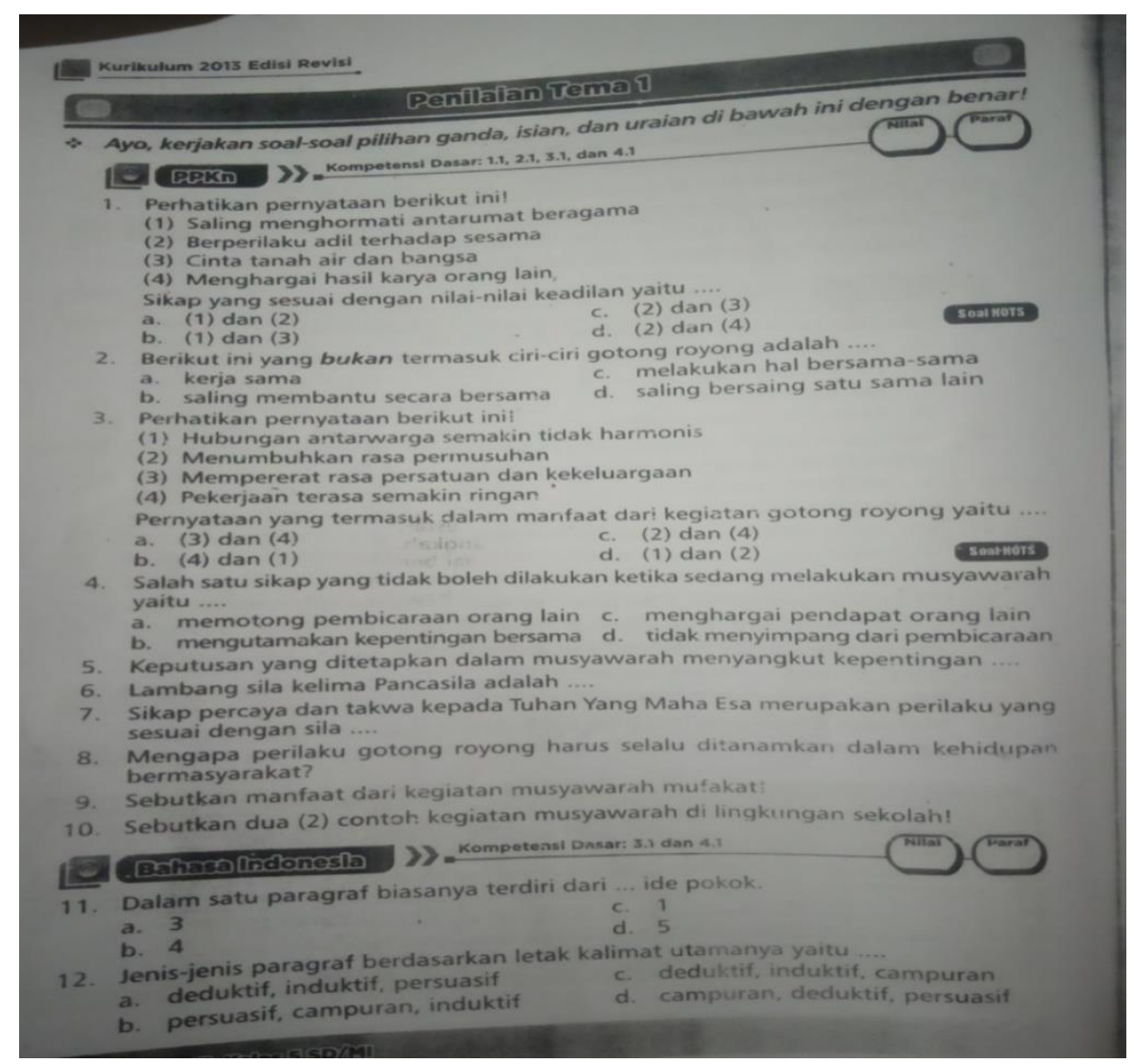

Gambar 4 : Contoh Penilaian Tema I

Sedangkan dalam buku terbitan Permendikbud siswa lebih banyak diminta untuk mengamati, menulis, merenungkan, berdiskusi, dan berkreasi semuanya dipaparkan satu persatu berbentuk soal yang harus dikerjakan siswa. Setelah semua subtema dipelajari di dalam buku Terbitan permendikbud ini disajikan kegiatan yang berbasis proyek yang bisa dikerjakan siswa untuk mengasah 
kompetensi yang siswa miliki dan kegiatan berbasis Proyek tersebut disajikan per pembelajaran. Contohnya sebagai berikut:

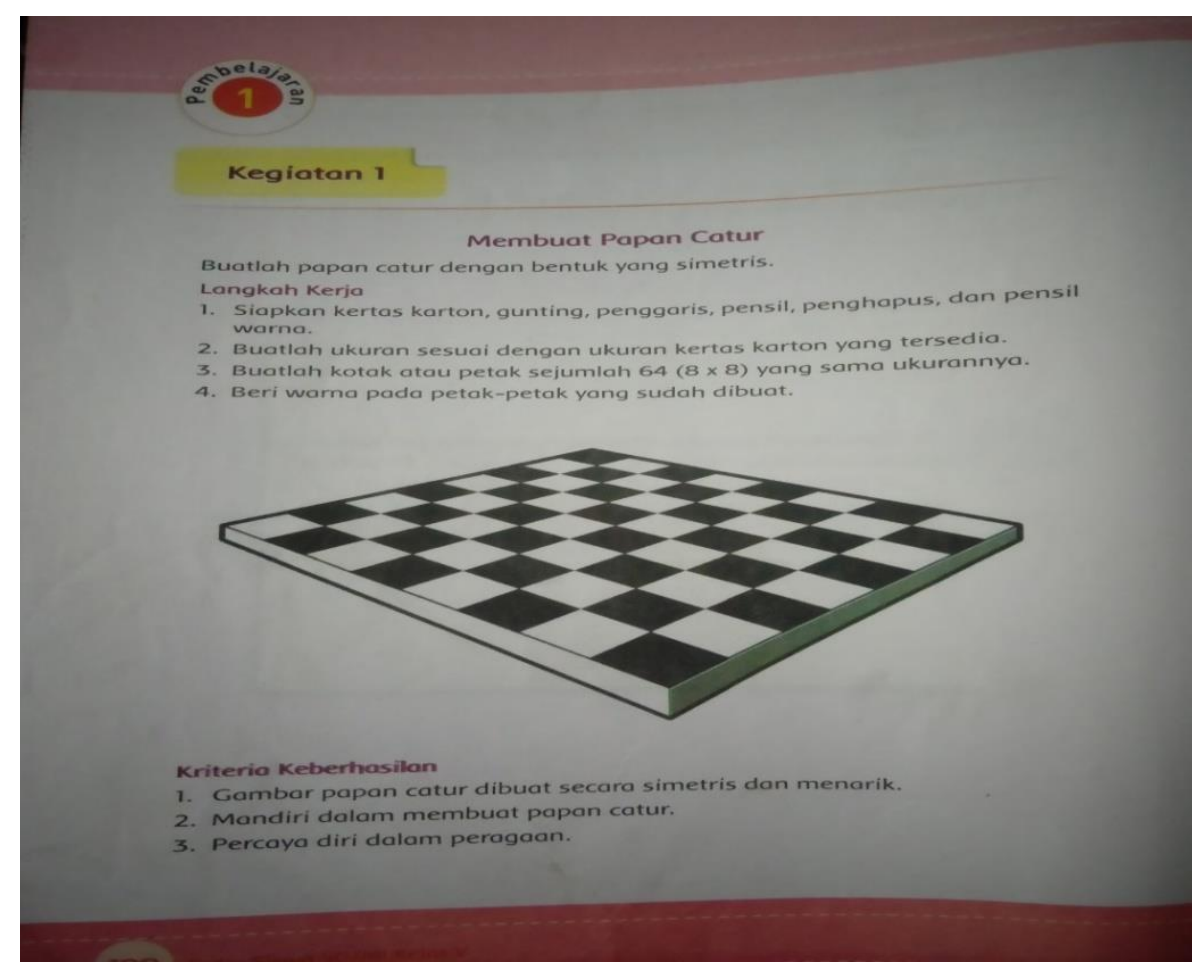

Gambar 5 : Kegiatan Berbasis Proyek Tema I Permendikbud

\section{B. Pembahasan}

Interpretasi hasil analisis hasil penelitian ini bahwa kurikulum 2013 sangat efektif dalam pembentukan karakter dan kompetensi siswa. Di mana proses pembelajaran kurikulum 2013 dikembangkan atas dasar prinsip pembelajaran siswa aktif melalui kegiatan mengamati (melihat, membaca, mendengar, menyimak),menanya (lisan,tulisan), menganalisis (menghubungkan menentukan keterkaitan, membangun cerita/konsep), mengkomunikasikan (lisan, tulisan, gambar, grafik, tabel, chart, dan lainnya).

Sesuai dengan pendapat di atas, proses pembelajaran pada kurikulum 2013 diawali dengan kegiatan mengamati oleh siswa dengan cara melihat, membaca, mendengar, dan menyimak tentang masalah yang berkaitan dengan materi pelajaran, setelah siswa mengamati, siswa dapat bertanya tentang apa yang dilihat, dibaca, didengar, dan disimak baik secara lisan maupun tulisan. Langkah selanjutnya kegiatan menganalisis dengan cara mengumpulkan informasi, menghubungkan informasi yang didapatkan oleh siswa, dan menentukan 
keterkaitan antara informasi yang satu dengan lainnya (mengolah informasi). Kegiatan akhir yang dilakukan oleh siswa adalah mengomunikasikan hasil pengamatan yang telah dibuat oleh siswa.

Pembelajaran kurikulum 2013 berdasarkan pada konsep bahwa pembelajaran merupakan suatu proses pengembangan potensi dan pengembangan karakter setiap siswa sebagai hasil dari sinergi antara pendidikan yang berlangsung di sekolah, keluarga, dan masyarakat. Proses kurikulum 2013 tersebut memberikan kesempatan kepada siswa untuk mengembangkan potensi mereka menjadi kemampuan yang semakin lama semakin meningkat dalam sikap (spiritual dan sosial), pengetahuan, dan keterampilan yang diperlukan dirinya untuk hidup dan bermasyarakat, berbangasa, serta berkontribusi pada kesejahteraan hidup umat manusia. ${ }^{11}$

Berkaitan dengan buku siswa terbitan Citra Pustaka dari segi pemaparan materi, dan soal yang disajikan sudah sesuai dengan standar proses pembelajaran kurikulum 2013. Di mana dalam buku tersebut soal atau bentuk latihan yang disajikan sudah mampu membuat siswa secara mandiri memecahkan suatu masalah yang mereka temukan baik di lingkungan sekolah dan di lingkungan tempat tinggal mereka. Karakter dan kompetensi yang siswa miliki bisa terbentuk sendiri dengan rangsangan-rangsangan yang diberikan oleh pendidik selama proses pembelajaran itu berlangsung, sehingga tujuan dari dilakukannya pembelajaran itu bisa terwujud sesuai dengan standar kompetensi lulusan.

Meskipun demikian, tidak bisa dipungkiri bahwa masih terdapat kekurangan-kekurangan sebagaimana yang sudah dijelaskan pada sebelumnya, namun hal tersebut tidak menjadi alasan bahwa buku ini tidak sesuai dengan standar proses pembelajaran kurikulum 2013, melainkan buku ini sudah memenuhi unsur yang terdapat pada standar kurikulum 2013

\section{KESIMPULAN}

Merujuk pada rumusan masalah berdasarkan hasil penelitian dan pembahasan terhadap bahan ajar tematik terbitan Citra Pustaka kelas V dapat

\footnotetext{
${ }^{11}$ Permendikbud, No. 104 Tahun 2014 Tentang Pembelajaran.
} 
diambil kesimpulan bahwa : Buku terbitan Citra pustaka ini isinya sudah sesuai dengan Standar Kompetensi Lulusan (SKL) dari Kompetensi Inti dan Kompetensi Dasar-nya. Namun tidak dipungkiri bahwa masih terdapat kekurangankekurangan sebagaimana yang sudah dijelaskan sebelumnya dari segi penyajian materi yang singkat dan tidak disajikannya contoh yang bisa dijadikan acuan oleh siswa, hal tersebut tidak menjadi alasan bahwa buku ini tidak sesuai dengan standar proses pembelajaran kurikulum 2013, karena buku ini sudah memenuhi unsur yang terdapat pada standarkurikulum 2013. 


\section{DAFTAR PUSTAKA}

Abdul Majid, (2013), Starategi Pembelajaran, Bandung: PT Remaja Rosdakarya.

Ali Imron, (2002), Kebijakan Pendidikan Di Indonesia Proses, Produk Masa

Dokumen Kurikulum 2013.

Moh Yamin, (2010), Menejemen Mutu Kurikulum Pendidikan, Jogjakarta : Dive Press, Cet-2 Februari.

Nana Syaodih Sukmadinanta, (1997), Pengembangan Kurikulum : Teori dan Praktek, Bandung : Remaja Rosdakarya.

Nur Sholeh, (2012), Sejarah Perkembangan Kurikulum Bahasa Arab Madrasah Aliyah 19984-2006, Tessis, Yogyakarta: UIN Sunan Kalijaga.

Pemendikbud No.57 Tahun 2013 Lampiran 3 Tentang Kurikulum 2013.

Permendikbud, No. 104 Tahun 2014 tentang Pembelajaran.

Sarjono, dkk, (2008), Panduan Penulisan Pendidikan, Yogyakarta: Jurusan Pendidikan Agama Islam Fakultas Tarbiyah Dan Keguruan UIN Sunan Kalijaga.

Suharsini Arikunto, (2006), Prosedur Penelitian Suatu Pendekatan Praktis, Jakarta: Rieneka Cipta.

UU No.20 Tahun 2003, tentang Sistem Pendidikan Nasional, Pasal 2. 